\title{
Physical Characterization of Two Wild Varieties of Edible Orchid Tubers
}

\author{
Dobgima J. Fonmboh ${ }^{1}$, Tembe Estella Achick ${ }^{2}$, Fokunang Charles Ntungwen ${ }^{2}$, Bup Nde Divine ${ }^{1, *}$ \\ ${ }^{1}$ Department of Nutrition, Food Science and Bio-resource Technology, The College of Technology, The University of Bamenda, Bambili, \\ Cameroon \\ ${ }^{2}$ Department of Pharmaco Toxicology and Pharmacokinetics, Faculty of Medicine and Biomedical Sciences, The University of Yaoundé 1, \\ Yaoundé, Cameroon
}

Email address:

bupdiv@yahoo.fr (B. N. Divine)

${ }^{*}$ Corresponding author

\section{To cite this article:}

Dobgima J. Fonmboh, Tembe Estella Achick, Fokunang Charles Ntungwen, Bup Nde Divine. Physical Characterization of Two Wild Varieties of Edible Orchid Tubers. Advances in Bioscience and Bioengineering. Vol. 7, No. 4, 2019, pp. 72-80.

doi: $10.11648 /$ j.abb.20190704.13

Received: October 27, 2018; Accepted: September 17, 2019; Published: November 19, 2019

\begin{abstract}
The physical properties of agricultural products are necessary for the design of equipment for post-harvest treatments and storage. The physical characteristics of two varieties (Ateehteu and Lamsie) of wild orchid tubers used for the production of an endogenously processed food eaten as a meat replacement were determined. Directly measured properties (tuber length, width, thickness, mass, true volume and bulk volume) and derived properties (sphericity, shape index, size, porosity, true and bulk density) were evaluated at $86.11 \%$ and $79.01 \%(\mathrm{wb})$ moisture contents of Ateehteu and Lamsie respectively. The mean ranges respectively recorded for Ateehteu and Lamsie were: mass (1.70 - 5.79) g; (1.24 - 7.65) g, length $(18.94$ - 32.01) mm; $(9.84$ - 27.54) mm, width (11.91 - 19.34) mm; (6.91 - 18.79) mm; thickness (5.07 - 24.50) mm; $(1.09-22.77) \mathrm{mm}$, true volume $(1.37-5.68) \mathrm{ml}$; $(1.52-7.28)$, and bulk volume $(29.67-30.58) \mathrm{ml}$; (31.50 - 32.84) $\mathrm{ml}$. For the derived properties, Ateehteu and Lamsie respectively gave, sphericity $(60.49-81.00) \%$; $(62.72-87.81) \%$, shape index $(1.18-2.34) \%$; $(1.08-2.19) \%$, true density $(0.58-1.82) \mathrm{g} / \mathrm{ml} ;(0.84-1.15) \mathrm{g} / \mathrm{ml}$, bulk density $(0.53-0.61) \mathrm{g} / \mathrm{ml} ;(0.50-$ $0.54) \mathrm{g} / \mathrm{ml}$, porosity $(0.76-1.00),(0.87-1.07)$; and bulk porosity $(0.47-0.51) ;(0.45-0.47)$. The repose angle was $(26.06-$ $32.92)^{\circ}$ and $(28.28-32.86)^{\circ}$ while the coefficient of static friction on four surfaces viz aluminium sheet, rubber, leather and plywood were $(0.27-0.44) ;(0.13-0.63),(0.32-0.49) ;(0.88-0.95),(0.16-0.64) ;(0.31-0.55) ;(0.33-0.62) ;(0.48-2.75)$. There were significant variations in physical dimensions of Lamsie; larger mass and true volume, sphericity and repose angle compared to Ateehteu. There was significant variation in the coefficient of static friction on aluminium sheet, rubber, leather and plywood respectively for Ateehteu and Lamsie respectively with no variation in the coefficient of dynamic friction on the same surfaces for Ateehteu and Lamsie respectively. The negative values obtained for some derived shape parameters (flattening and ellipticity) which consequently affected the surface area is an indication that the shape assumption of the tubers as oblate or prolate requires verification. There is therefore need to correlated the directly measured properties to obtain an empirical formula to calculate each corresponding parameter and analyse to obtain the best fit. It is therefore promising to design a process plan to harvest, transports, handle, sort and separate, grade, convey stock and process the tubers into Nyam $n g u b$.
\end{abstract}

Keywords: Physical Characteristics, Wild Orchid, Tubers, Varieties, Ateehteu, Lamsie, Nyam ngub

\section{Introduction}

Nyam ngub (figure 1) is an endogenously process product consumed as a meat snack, meat sausage or meat substitute by many localities in the North West Region of Cameroon though civilization and land exploitation has relegated it only to certain localities. Nyam ngub is processed from the tubers and roots of certain wild orchid plants that flourish the cold hills of areas like Fomejih, Bali Nyonga, Belo, Kedjom 
Ketingoh Kumbo, Ndu and Nkambe between the months of July to October. Although Nyam ngub represent a delicacy in these areas, nothing seems to be done to stop it from being seasonal and the tradition of tuber collection, processing and Nyam ngub consumption is rapidly being abandoned with little traces of the activity left in the hands of the some elderly persons. The scarcities of information on the tubers as well as Nyam ngub seem to be contributing to the prevailing situation. In addition, the perishability and bulkiness of the tubers and the collection method as well as the collection tools expose the tubers to harvest and post-harvest damages. In order to design equipment and facilities for the handling, conveying, grading and separation, drying, aeration, storing, packing, processing (conversion of the materials to food and/ or feed) and packaging of the tubers, an insight information on the physical characteristics is essential [1]. This basic information is not only significant to engineers but also to food scientists, processors, and other scientists who may exploit the data and find new uses [2].

Knowledge of the length, width, volume, surface area and mass of biological materials may be applied in the designing of sorting machinery, in predicting surface needed when applying chemicals, shape factor (sphericity) [3]. The major moisture-dependent physical properties of biological materials are shape and size, densities, porosity, mass and friction against various surfaces [2].

The size and shape are important in the electrostatic separation from undesirable materials and in the development of sizing and grading machinery [4]. The shape of the material is important for an analytical prediction of the drying behaviour [2] and is exploited singly or together with other characteristics to determine the free flowing or bridging tendencies of a seed mass in many separators used in seed cleaning [5].

Bulk density and porosity are the major considerations in designing near-ambient drying and aeration systems, as these properties affect the resistance to airflow of the stored mass. Porosity is useful in the calculation of rate of aeration and cooling, drying and heating and the design of heat exchangers and other similar equipment [6]. The theories used to predict the structural loads for storage structures have bulk density as a basic parameter [2].

The frictional characteristics are important for the proper design of harvesting, conveying, handling [7], sorting and separation, grading, processing, storage, etc [8]. The angle of repose is important in designing the equipment for mass flow and structures for storage [2]. The coefficient of static friction is used to determine the angle at which chutes must be positioned in order to achieve consistent flow of material through the chute [8]. In addition, this coefficient is important in the designing of conveyors because friction is necessary to keep the material to the conveying surface without slipping or sliding backward [9].

Surface area and volume of food is an important physical characteristic in processes such as harvesting, cleaning, separation, handling, aeration, drying, storing, milling, cooking and germination [10] and yield during peeling [3].
Volumes and surface areas of solids must be known for accurate modelling of heat and mass transfer during cooling and drying.

Quality differences in fruits, vegetables, grain and seeds can often be detected by differences in density [11]. Density data of foods are required in separation processes, such as centrifugation and sedimentation, and in pneumatic and hydraulic transport of powders and particulates [12, 13]. When fruits and vegetables are transported hydraulically, the designed fluid velocities are related to both density and shape.

Due to the irregular nature of the shape and sizes of agricultural products, the coefficient of variation (Cov) was used to characterize the quality of dispersion to the measured parameters about their means. Low Covs therefore, indicated more uniform dispersion [5].

There are situations in agricultural product management where information on the relationships among physical characteristics is desirable. For example, grading is often done by size, but it might be more economical to develop a machine which grades by weight in which case, the relationship between weight and the major, minor and intermediate diameters is necessary [14]. Determining a relationship between mass, dimensions and projected areas is useful and applicable in sizing by weight [15].

These properties have been studied for various crops and for numerous purposes. For example soybean [16], pumpkin grains [17], sunflower [18], green gram [19], pigeonpea [20]. Others studied the black-eyed pea [21], some grain legume seeds [22], and faba bean [23]. Also, potato [24, 25], orange and apple [26, 27], okro fruit [28], caper fruit [29], apple [30], four orange varieties [31], date (cv. Lasht) [11], pomegranate [32], hydro-sorting of potato [33] and the physical dimensions of some orchid tubers [34].

The objective of this study was to investigate some physical properties of two wild orchid tubers. These properties were the physical dimensions, unit mass and volume, shape, size, densities, porosity, surface area, repose angle, coefficient of rolling friction against four structural surfaces. The mass, volume, shape and size of tubers was then predicted based on the dimensions, projected area and volume. This information will be used in the design and development of appropriate equipment and technologies for the processing of the tubers into process product known as Nyam ngub (Figure 1).

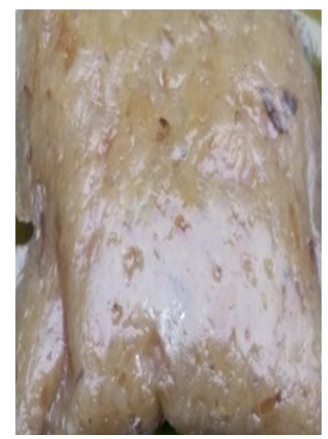

(a) Nyam ngub from Ateehteu. 


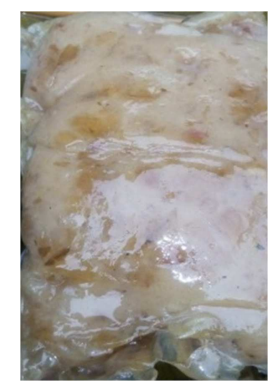

(b) Nyam ngub from Lamsie.

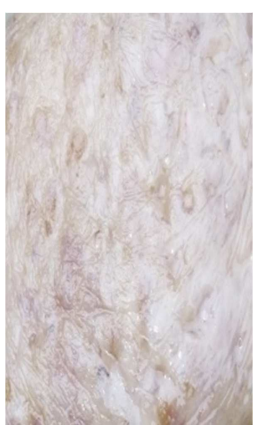

(c) Nyam ngub from Ateehteu and Lamsie. Source: Courtesy of DOBGIMA FONMBOH.

Figure 1. Nyam ngub.

\section{Methodology}

\subsection{Sample Collection}

The tuber of two wild varieties of orchid cultivars; Ateehteu and Lamsie (figure 2) were harvested from Abong Phen village in Kedjom Ketingoh in August and September 2017 with the help of local collectors and processors. The tubers were cleaned manually with running tap water to remove all foreign matter such as dead coat, soil and stones and then drained at ambient temperature on absorbing clothes, sorted and selected.

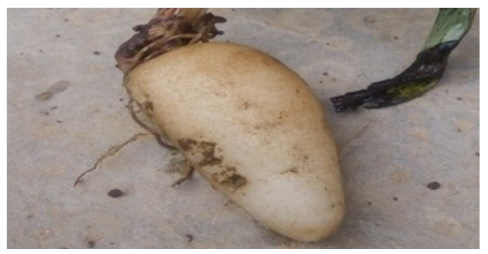

(a) Ateehteu tuber.

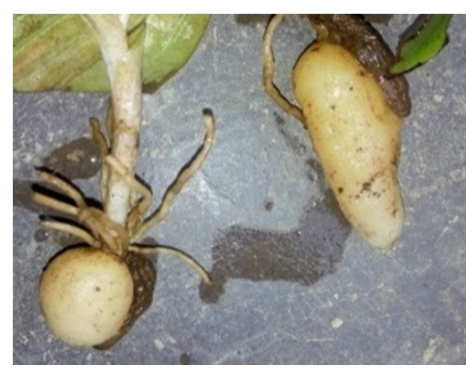

(b) Lamsie tuber.

Source: Courtesy of Dobgima Fonmboh.

\subsection{Sample Analysis}

The investigation was undertaken at the Nutrition Food Science and Bioresource Technolopgy laboratory in the College of Technology of The University of Bamenda. Studies were conducted to evaluate the physical properties of two wild varieties of orchid tubers. The determination of physical properties of food materials was much complex due to the irregular shape and variability in size of the materials. The procedures for the determination of physical properties of the two wild orchid tubers are presented. All experiments were carried out at a temperature range of $25-27^{\circ} \mathrm{C}$ in three days.

\subsubsection{Moisture Content}

Initial moisture content of samples was determined by hot air oven drying method as recommended by AOAC (2000) [35].

\subsubsection{Tuber Dimensions}

The average grain dimension was measured by randomly picking 124 Ateehteu and 195 Lamsie. The three linear dimensions namely length (L), Width (W) and Thickness (T) were measured using an electronic digital Vernier calliper (least count $0.01 \mathrm{~mm}$ ).

\subsubsection{Tuber Mass}

The mass (m) of each of the tubers used for the physical dimension evaluation was measured with an electronic precision balance of $0.01 \mathrm{~g}$ accuracy.

\subsubsection{True Volume}

True volume $\left(\mathrm{V}_{\mathrm{T}}\right)$ was measured with a measuring cylinder by the water displacement method using distilled water. Distilled water was introduced in a graduated measuring cylinder and the volume noted $\left(\mathrm{V}_{1}\right)$. A tuber of known mass was then gently introduced into the measuring cylinder and the new volume $\left(\mathrm{V}_{2}\right)$ recorded after the tuber had settled at the bottom of the cylinder. The change in volume $V_{2}-V_{1}$ was then recorded as the true volume of the tuber.

\subsubsection{Bulk Volume and Void Volume}

The bulk volume $\left(\mathrm{V}_{\mathrm{b}}\right)$ of each cultivar was determined by measuring the mass of a known volume of bulk sample. A bulk sample of each tuber species was placed in a $250 \mathrm{ml}$ cylindrical cylinder with 5 gentle vertical tapping on the desk to assure consistent packing. The excess tubers on the top of the cylinder were removed by sliding a string along the top edge of the cylinder.

The void volume $\left(\mathrm{V}_{\mathrm{v}}\right)$ was determined by packing a known mass of the tubers in a $500 \mathrm{ml}$ graduated measuring cylinder with 5 gentle taps vertically on the table until no diminution of tuber volume with the taping. The volume was noted and distilled water was added on to the tubers in the cylinder to the noted volume mark. The water was immediately drained in another measuring cylinder and the volume which represented the void volume noted.

Figure 2. Two varieties of wild orchid tubers. 


\subsubsection{Diameter}

Arithmetic mean diameter (AMD), Geometric mean diameter (GMD), Square mean diameter (SMD) and Equivalent diameter (EQD) of the tubers were calculated from the physical dimensions by using the following equations $[36,2,8,37]$.

$$
\begin{gathered}
\operatorname{AMD}\left(D_{A}\right)=\frac{L+W+T}{3} \\
\operatorname{GMD}\left(D_{G}\right)=(L W T)^{1 / 3} \\
\operatorname{SMD}\left(D_{S}\right)=[(L W)+(W T)+(T L)]^{1 / 2} \\
\operatorname{EQD}\left(D_{E}\right)=\frac{D_{A}+D_{G}+D_{S}}{3}
\end{gathered}
$$

\subsubsection{Sphericity}

The sphericity $(\Phi)$ of tubers was calculated by using the following relationship given by [4]:

$$
\text { Sphericity }(\phi)=\frac{(L W T)^{1 / 3}}{L}
$$

\subsubsection{Shape Factor $(\lambda)$}

Shape factor $(\lambda)$ based on volume and surface area of bean was determined as recommended by McCabe and Smith [38].

$$
\text { Shape factor }(\lambda)=\frac{a}{b}
$$

Where;

$$
\begin{aligned}
& a=\frac{\mathrm{v}}{\mathrm{W}^{3}} \\
& \mathrm{~b}=\frac{\mathrm{A}}{\mathrm{W}^{2}}
\end{aligned}
$$

$\mathrm{V}=$ volume; $\mathrm{W}=$ width and $\mathrm{A}=$ surface area.

\subsection{Other Physical Properties Analysis}

\subsubsection{Shape Index}

The shape index of the measured samples was calculated according to $[39,40]$ as follows:

$$
\text { Shape index }(I)=\frac{L}{\sqrt{W T}}
$$

\subsubsection{Aspect Ratio $\left(\boldsymbol{R}_{a}\right)$}

The aspect ratio is an indicator of a tendency towards a particular shape [41]. It is calculated using the length $(L)$ and the width $(W)$ of a sample following the recommendation of [42] from:

$$
\text { Aspect ratio }\left(\mathrm{R}_{\mathrm{a}}\right)=\frac{\mathrm{w}}{\mathrm{L}}
$$

\subsubsection{Flattening or Oblateness (f)}

Flattening is a measure of the degree to which the spheroid has been flattened and is given by:

$$
\text { Flattening }(f)=1-\frac{L}{W}
$$

\subsubsection{Ellipticity ( $\epsilon)$}

Ellipticity is a function of the particle shape with values indicating the deviation from a spherical shape. It is obtained from:

$$
\begin{gathered}
\epsilon_{\text {oblate }}=\sqrt{\left(\left(1-\frac{\mathrm{L}}{\mathrm{W}}\right)\left(1+\frac{\mathrm{L}}{\mathrm{W}}\right)\right)} \\
\epsilon_{\text {prolate }}=\sqrt{\left(1-\frac{\mathrm{W}^{2}}{\mathrm{~L}^{2}}\right)}
\end{gathered}
$$

\subsubsection{Surface Area $\left(A_{S}\right)$}

The surface area is related to the size but also depends on particle shape and it is a function of the polar and equatorial radii and the ellipticity $(\epsilon)$ which is a measure of how the spheroid deviates from being a sphere. The surface area was calculated as recommended by [1] as follows:

$$
\begin{gathered}
A_{\text {Soblate }}=2 \pi \mathrm{W}^{2}+\pi \frac{\mathrm{L}^{2}}{\epsilon} \ln \left(\frac{1+\epsilon}{1-\epsilon}\right) \\
\mathrm{A}_{\text {Sprolate }}=2 \pi \mathrm{T}^{2}+\frac{2 \pi \mathrm{W}}{\epsilon} \sin ^{-1} \epsilon
\end{gathered}
$$

\subsubsection{Solid Volume $\left(V_{S}\right)$}

The major dimension of the tubers was used to calculate the volume $(\mathrm{V})$ of a tuber considering it as a sphere as given below:

$$
V_{S}=\frac{4}{3} \pi \mathrm{W}^{2} \mathrm{~L}
$$

\subsubsection{Bulk and True Density ( $\rho)$}

The bulk density of packed materials depended on the geometry, size, and surface properties of each particle [43]. The particle, substance or true density was the density of a particle including the volume of all closed pores but not the externally connected pores when the particle was not modified structurally. It was calculated as proposed by [44]

$$
\operatorname{Density}(\rho)=\frac{\operatorname{Mass}(\mathrm{m})}{\operatorname{Volume}(\mathrm{v})}
$$

\subsubsection{Porosity ( $\varepsilon$ )}

Porosity depended on the geometry and surface properties of a material. The percent voids of an unconsolidated mass of material such as grain, hay and other porous materials are often needed in air flow and heat flow studies [37]. It was defined as the volume fraction of the air or the void fraction in the sample expressed as:

$$
\text { Porosity }=\frac{\text { Void volume }}{\text { Total volume }}
$$

The bulk porosity includes the void volume outside the boundary of individual particles when stacked as bulk and calculated from the bulk and apparent volumes and densities as:

\subsection{Analysis of Angle of Response, Static and Dynamic Friction}

\subsubsection{Angle of Repose $\left(\theta_{r}\right)$}

The Angle of Repose (AOR) was determined by using a topless and bottomless cylinder of $10 \mathrm{~cm}$ diameter and $15 \mathrm{~cm}$ height. The cylinder was placed on a table and filled with the tubers of each cultivar with gentle tapping by the sides for 
packing. The cylinder was then slowly raised to liberate the tubers at the bottom in a heap (cone). The diameter (D) and height $(\mathrm{H})$ of cone was recorded and the angle AOR was calculated by using the formula recommended by [45] as follows:

$$
\theta_{r}=\operatorname{Tan}^{-1}\left(\frac{2 H}{D}\right)
$$

\subsubsection{Coefficient of Static and Dynamic Friction}

The coefficients of static friction were obtained with respect to four different surfaces, namely galvanized Aluminium sheet, rubber, plywood and synthetic leather surfaces, by using a locally fabricated inclined plane (figure 1) adapted from the TMI inclined plane apparatus as described by [46].

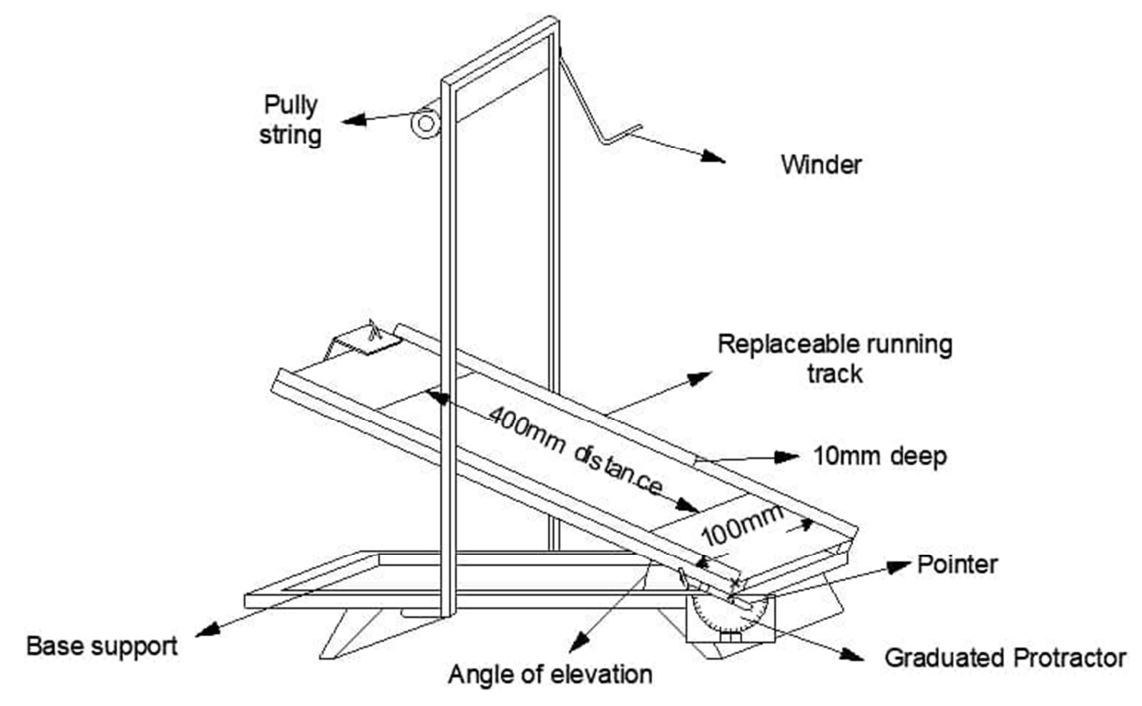

Figure 3. Sketch of the locally fabricated inclined plane showing elevation of replaceable runway.

The inclined plane was gently raised and the angle of inclination at which the sample started sliding or rolling was read off the protractor ( $1^{\circ}$ sensitivity) while the time taken for the tuber to cover a $400 \mathrm{~mm}$ distance was taken with an electronic digital stop watch $(0.001 \mathrm{~s}$ precision). The tangent of the angle was reported as the coefficient of static friction [47].

$$
\mu_{S}=\operatorname{Tan}(\alpha)
$$

Where $\mu_{\mathrm{S}}=$ static coefficient; $\alpha=$ angle of inclination that forced the sample to move.

While the coefficient of dynamic friction was obtained as reported by [48] as follows:

$$
\mu_{\mathrm{D}}=\frac{\mathrm{F}}{\mathrm{mg}}
$$

Where

$$
\mathrm{F}=\mathrm{mg} \cos \alpha
$$

$\mu_{D}=$ coefficient of dynamic friction; $F=$ normal force; $\mathrm{m}=$ mass of sample; $\mathrm{g}=$ acceleration due to gravity; $\alpha=$ angle of inclination of the plane that caused sample to move.

\subsection{Statistical Analysis}

The data was collected on a Microsoft word 2010 excel spreadsheet and Sigma Plot trial version 14 was utilized to carry out One way RM ANOVA analysis with Duncan test used to separate the values and to determine regression models between the parameters.

\section{Results and Discussion}

The physical property of the two wild varieties of orchid tubers was evaluated. This included axial dimension viz., length (L), width (W), thickness (T), AMD, GMD, SMD, EQD, moisture content, true volume, solid volume, surface area, sphericity, aspect ratio, shape factor, shape index, mass, particle density, bulk density, porosity, bulk porosity, angle of repose and coefficient of static and dynamic friction on Aluminium sheet, Rubber, Leather, and plywood.

\subsection{Moisture Content and Axial Dimensions of the Tubers}

The moisture content and axial dimensions are shown on table 1. The moisture content (MC) was higher for Ateehteu $(86.11 \%)$ than Lamsie $(79.01 \%)$ and showed significant difference at $\mathrm{p} \leq 0.05$. The major (Length, L), intermediate (Width, W) and minor (Thickness, T) diameters for Ateehteu measured $25.48 \mathrm{~mm}, 15.62 \mathrm{~mm}$ and $14.79 \mathrm{~mm}$ respectively while Lamsie measured $18.69 \mathrm{~mm}, 12.85 \mathrm{~mm}$ and $11.93 \mathrm{~mm}$ respectively. Ateehteu was longer, larger and thicker than Lamsie and showed significant difference at $\mathrm{p} \leq 0.05$. These length and width are comparable to those measured for some Orchids species. The tuber length and width were 17.3, and $11.7 \mathrm{~mm}$ for $O$. anatolica, 30.9 and $20.5 \mathrm{~mm}$ for $O$. italic, 22.9 and $17.6 \mathrm{~mm}$ for $O$. laxiflora, 19.9 and $17.5 \mathrm{~mm}$ for $O$. morio sub sp morio, 21.1 and $14.9 \mathrm{~mm}$ for $O$. provincialis, 44.8 and $36.7 \mathrm{~mm}$ for $O$. purpurea 21.7 and $15.8 \mathrm{~mm}$ for $O$. sancta, 26.5 and $21.8 \mathrm{~mm}$ for simia and 26.2 and $17.1 \mathrm{~mm}$ for O. tridentate [34]. 
Table 1. Moisture content and axial ddimensions of the tubers.

\begin{tabular}{lll}
\hline Property & Ateehteu & Lamsie \\
\hline MC \% & $87.06 \pm 0.57^{\mathrm{a}}$ & $89.43 \pm 0.50^{\mathrm{a}}$ \\
Length (mm) & $25.48 \pm 6.53^{\mathrm{a}}$ & $18.69 \pm 8.85^{\mathrm{b}}$ \\
Width $(\mathrm{mm})$ & $15.62 \pm 3.71^{\mathrm{a}}$ & $12.85 \pm 5.94^{\mathrm{b}}$ \\
Thickness $(\mathrm{mm})$ & $14.79 \pm 9.712^{\mathrm{a}}$ & $11.93 \pm 10.84^{\mathrm{b}}$ \\
\hline
\end{tabular}

MC: Moisture content; \%: percentage.

Values expressed are mean \pm standard deviation.

Means on the same row with different superscript are significantly different at $\mathrm{p} \leq 0.05$

\subsection{Mass and True Volume}

The mass and true volume of the tubers is presented on table 2. Lamsie variety was significantly heavier and occupied more space than the Ateehteu variety $(\mathrm{p} \leq 0.05)$. The masses ranged from $(1.240$ - 7.648) $\mathrm{g}$ for Lamsie and $(1.704-5.785) \mathrm{g}$ for Ateehteu while the true volume ranged from $(1.52-7.28) \mathrm{ml}$ for Lamsie and (1.27 - 5.68) $\mathrm{ml}$ for Ateehteu. Mass and weight measurements will be useful in the design of cleaning equipment using aerodynamic forces, separators, and conveyors as well as serve as an index to estimate the relative amount of dockage for these tubers $[50,51]$.

Table 2. Mass and True volume of the tubers.

\begin{tabular}{lll}
\hline Dimensions & Ateehteu & Lamsie \\
\hline Mass $(\mathrm{g})$ & $3.74 \pm 2.04^{\mathrm{a}}$ & $4.44 \pm 3.20^{\mathrm{b}}$ \\
True Volume $(\mathrm{ml})$ & $3.53 \pm 2.15^{\mathrm{a}}$ & $4.40 \pm 2.88^{\mathrm{b}}$ \\
\hline
\end{tabular}

Values expressed are mean \pm standard deviation.

Means on the same row with different superscript are significantly different at $\mathrm{p} \leq 0.05$.

\subsection{Diameters, Surface Area and Solid Volume}

Table 3 presents the values obtained for the diameters, surface area and solid volume. The AMD $\left(D_{A}\right)$, GMD $\left(D_{G}\right)$, SMD $\left(\mathrm{D}_{\mathrm{S}}\right)$ and EQD $\left(\mathrm{D}_{\mathrm{E}}\right)$ of Ateehteu were higher than those of Lamsie and showed significant difference at $\mathrm{p} \leq 0.05$. The corresponding ranges for the diameters were $(13.10-24.15)$ $\mathrm{mm},(7.23-21.75) \mathrm{mm},(12.978-22.62) \mathrm{mm}$ and $(7.46-$ 20.39) $\mathrm{mm}$ respectively for Ateehteu while Lamsie was (22.70 - 40.25) mm, (12.94 - 36.18) mm, (12.94 - 36.18) mm and $(9.24-26.07) \mathrm{mm}$ respectively. The surface area when considered as an oblate was $(910.22-2326.27) \mathrm{mm}^{2}$ and $(515.40-2001.44) \mathrm{mm}^{2}$ for Ateehteu and Lamsie respectively while the calculated volume was $(10280.02-48911.29) \mathrm{mm}^{3}$ for Ateehteu and (6704.31 - 31539.78) $\mathrm{mm}^{3}$ for Lamsie.

Table 3. Various diameters and surface areas of the tubers.

\begin{tabular}{lll}
\hline Parameters & Ateehteu & Lamsie \\
\hline AMD (mm) & $18.63 \pm 5.52^{\mathrm{a}}$ & $14.49 \pm 7.26^{\mathrm{b}}$ \\
GMD (mm) & $17.80 \pm 4.82^{\mathrm{a}}$ & $13.93 \pm 6.46^{\mathrm{b}}$ \\
SMD (mm) & $31.47 \pm 8.77^{\mathrm{a}}$ & $24.56 \pm 11.62^{\mathrm{b}}$ \\
ED (mm) & $22.63 \pm 6.36^{\mathrm{a}}$ & $17.66 \pm 8.42^{\mathrm{b}}$ \\
Surface area o $(\mathrm{mm} 2)$ & $1618.24 \pm 708.03^{\mathrm{a}}$ & $1258.42 \pm 743.02^{\mathrm{b}}$ \\
Solid volume $(\mathrm{mm} 3)$ & $29595.65 \pm 19315.63^{\mathrm{a}}$ & $19122.05 \pm 12417.73^{\mathrm{b}}$ \\
\hline
\end{tabular}

AMD: Arithmetic mean diameter; GMD: Geometric mean diameter; SMD: Square mean diameter; ED: Equivalent diameter. o: Oblate; p: prolate.

Values expressed are mean \pm standard deviation.

Means in the rows with different superscript are significantly different at $\mathrm{p} \leq 0.05$.

\subsection{Shape Parameters}

Table 4 presents the results of the shape parameters. The mean sphericity, aspect ratio and shape index were significantly different $(\mathrm{p} \leq 0.05)$ between the two varieties and ranged from $60.49-81.00 \%, 50.36-75.17 \%$ and $(1.18-$ $2.34)$ respectively for Ateehteu. The corresponding ranges for Lamsie were 62.72 - 87.81\%, 52.15 - 87.54\% and $(1.06-$ $2.19)$. The sphericity and aspect ratio of more than $70 \%$ implied that grain was more as a sphere and tend to rather roll than slide [46]. The low value of aspect ratio indicated the tendency to slide than to roll [2]. Buyanov and Voronyuk [49] mentioned that, if sphericity is less than 0.9, fruits are oblate and if greater than 1.1 the fruits were oblong. Gamea [40] indicated that when $\mathrm{I} \leq 1.5$, product is spherical while $\mathrm{I} \geq 1.5$, product is oval.

Table 4. Shape parameters.

\begin{tabular}{lll}
\hline Parameters & Atehteu & Lamsie \\
\hline Sphericity (\%) & $70.74 \pm 10.26^{\mathrm{a}}$ & $75.26 \pm 12.54^{\mathrm{b}}$ \\
Aspect ratio (\%) & $122.10 \pm 150.36^{\mathrm{a}}$ & $109.38 \pm 142.23^{\mathrm{b}}$ \\
Shape index & $1.76 \pm 0.58^{\mathrm{a}}$ & $1.62 \pm 0.57^{\mathrm{b}}$ \\
\hline
\end{tabular}

Values expressed are mean \pm standard deviation.

Means in the same row with different superscripts are significantly different at $\mathrm{p} \leq 0.05$.

\subsection{Derived Gravimetric Parameters}

Table 5 shows the gravimetric parameters and frictional properties of the two wild varieties of orchid tubers. The true density ranged from $(0.58-1.82) \mathrm{g} / \mathrm{cm}^{3}$ for Ateehteu and $(0.84-1.15) \mathrm{g} / \mathrm{cm}^{3}$ for Lamsie and indicated that Ateehteu is significantly denser than $(\mathrm{p} \leq 0.05)$. The material density had no significant difference $(\mathrm{p} \leq 0.05)$ for the two cultivars and range from $(0.90-1.01) \mathrm{g} / \mathrm{cm}^{3}$ for Ateehteu and $(0.91-0.97)$ $\mathrm{g} / \mathrm{cm}^{3}$ for Lamsie. The bulk density ranged from $(0.53-0.61)$ $\mathrm{g} / \mathrm{cm}^{3}$ and $(0.50-0.54) \mathrm{g} / \mathrm{cm}^{3}$ for Ateehteu and Lamsie respectively and were significantly different $(\mathrm{p} \leq 0.05)$.

The true density was reported to be $1.10 \mathrm{~g} / \mathrm{cm}^{3}$ for Diamont and Santana potato species (Nuwamanya et al., 2011; Gamea, 2009). Yossry \& Elhay (2017) indicated values of $1.12 \mathrm{~g} / \mathrm{cm}^{3}$ for Asterix, $1.15 \mathrm{~g} / \mathrm{cm}^{3}$ for diamond and 1.19 $\mathrm{g} / \mathrm{cm}^{3}$ for Santana potato species. The quality of food materials can be assessed by measuring their densities. Density data of foods are required in separation processes, such as centrifugation and sedimentation, and in pneumatic and hydraulic transport of powders and particulates (Sahin and Gülüm Sumnu, 2006; Gorji Chakespari et al., 2010).

The internal porosity ranged from $(76.16-99.50) \%$ and (86.85 - 107.33)\% for Ateehteu and Lamsie respectively and were significantly different $(\mathrm{p} \leq 0.05)$ for the two varieties. The bulk porosity for Ateehteu and Lamsie range from $(0.43$ - 0.48$) \%$ and $(0.47-0.51) \%$ respectively, significantly different at $\mathrm{p} \leq 0.05$. Porosity characterizes the texture and quality of dry and intermediate moisture foods and the data is necessary in modelling and design of various heat and mass transfer processes as well as in predicting diffusional properties of cellular foods (Gamea et al., 2017; Yossry \& 
Elhay, 2017).

Table 5. Gravimetric properties.

\begin{tabular}{lll}
\hline Properties & Atehteu & Lamsie \\
\hline True Density $(\mathrm{g} / \mathrm{cm} 3)$ & $1.05 \pm 0.03^{\mathrm{a}}$ & $1.03 \pm 0.03^{\mathrm{b}}$ \\
Material density $(\mathrm{g} / \mathrm{cm} 3)$ & $0.95 \pm 0.06^{\mathrm{a}}$ & $0.94 \pm 0.03^{\mathrm{a}}$ \\
Bulk Density $(\mathrm{g} / \mathrm{cm} 3)$ & $0.57 \pm 0.04^{\mathrm{a}}$ & $0.52 \pm 0.02^{\mathrm{b}}$ \\
Porosity $(\%)$ & $0.88 \pm 0.12^{\mathrm{a}}$ & $0.97 \pm 0.10^{\mathrm{b}}$ \\
Bulk porosity (\%) & $0.49 \pm 0.02^{\mathrm{a}}$ & $0.46 \pm 0.01^{\mathrm{b}}$ \\
\hline
\end{tabular}

AMD: Arithmetic mean diameter; GMD: Geometric mean diameter; SMD: Squared mean diameter; ED: Equivalent diameter. O: Oblate; P: Prolate.

Values expressed are mean \pm standard deviation.

Means in the rows with different superscript are significantly different at $\mathrm{p} \leq 0.05$

\subsection{Frictional Properties}

The results of the frictional properties are presented on table 6. The static coefficient of friction of Ateehteu was 0.35 on aluminium sheet, 0.40 on rubber, 0.40 on synthetic leather and 0.48 on plywood. The corresponding values for Lamsie were 0.38 on aluminium sheet, 0.42 on rubber, 0.43 on synthetic leather and 1.62 on plywood significantly different $(p \leq 0.05)$ between the two species on the surfaces studied. These values are comparable to the sliding and rolling coefficients of unpeeled potato that were 0.49 and 0.28 on galvanized iron; 0.64 and 0.36 on wood (Dalvand, 2011).

The repose angle was $28.05^{\circ}$ and $26.20^{\circ}$ for Ateehteu and Lamsie respectively and showed no significant difference $\left(\mathrm{p} \leq 0.05\right.$ ). Nuwamanya et al., (2011) obtained $31.33^{\circ}$ and $35.28^{\circ}$ for Diamont and Santana potato species while Gamea et al. (2009) reported $31^{\circ}$ and $34^{\circ}$ for the respective potato species.

The static coefficient of friction is used to determine the positional angle of chutes to maintain a consistent flow of materials through the chute (Olajide \& Igbeka, 2003) and is applicable in sizing motor requirements for material transportation, handling, and designing conveying equipment (Varnamkhasti et al., 2008).

Table 6. Frictional properties of tubers.

\begin{tabular}{|c|c|c|}
\hline \multicolumn{3}{|c|}{ Coefficient of Static Friction } \\
\hline & Ateehteu & Lamsie \\
\hline Alu & $0.35 \pm 0.08^{\mathrm{a}}$ & $0.38 \pm 0.25^{\mathrm{b}}$ \\
\hline $\mathrm{Ru}$ & $0.40 \pm 0.09^{\mathrm{a}}$ & $0.42 \pm 0.11^{\mathrm{b}}$ \\
\hline SL & $0.40 \pm 0.24^{\mathrm{a}}$ & $0.43 \pm 0.12^{\mathrm{b}}$ \\
\hline $\mathrm{Pl}$ & $0.48 \pm 0.15^{\mathrm{a}}$ & $1.62 \pm 1.13^{\mathrm{b}}$ \\
\hline $\operatorname{AOR}\left({ }^{\circ}\right)$ & $28.05 \pm 2.04^{\mathrm{a}}$ & $26.20 \pm 5.04^{\mathrm{a}}$ \\
\hline
\end{tabular}

Al: Aluminium sheet; Ru: Rubber; SL: Synthetic leather; Pl: Plywood; COSF: Coefficient of Static friction; CODF: Coefficient of dynamic friction; AOR: Angle of repose.

Values expressed are mean \pm standard deviation.

Means in the rows with different superscript are significantly different at $\mathrm{p} \leq 0.05$ for Atehteu and Lamsie on the studied surfaces.

\section{Conclusion}

The physical properties of two wild orchid tubers used in the production of a traditional food consumed either as snack, meat sausage and/or meat substitute was studied.
There were significant variations in physical dimensions of Lamsie, larger mass and true volume, sphericity and repose angle compared to Ateehteu. There was significant variation in the coefficient of static friction on aluminium sheet, rubber, leather and plywood were respectively for Ateehteu and Lamsie respectively with no variation in the coefficient of dynamic friction on the same surfaces for Ateehteu and Lamsie respectively.

\section{Conclusion}

The negative values obtained for some derived parameters like flattening and ellipticity which consequently affected the surface area was an indication that the shape assumption of the tubers to be oblate and/ or prolate required verification. There was therefore need to model the different possible formulae for the calculation of each parameter and analysis to obtain the best fit. A process plan can therefore be a promising design to harvest, transports, handle, sort and separate, grade, convey, stock and process the tubers into Nyam ngub.

\section{Acknowledgements}

The authors wish to thank Dr. Tacham W. Ndam, Dr. Benyella L. Tita and Prof. Ejoh R. Abba for their technical support. The Food Science and Technology laboratory and the Animal Production laboratory of the College of Technology and the Chemistry laboratory of the Faculty of Science of The University of Bamenda for the technical support.

\section{References}

[1] Teye E. and Abano E. E. Physical properties of two varieties of sweet potato grown in coastal savannah zone of ghana. I. J. S. N., 2012; 3 (1): 105-109. ISSN 2229-6441.

[2] Singh Yogendra and Suresh Chandra Evaluation of physical properties of kidney beans (Phaseolus vulgaris). Food Sci. Re. Paper Res. J, 2014; 5 (2): 125-129. ISSN-2230-9403. DOI: 10.15740/HAS/FSRJ/5.2/125-129Wright 1986.

[3] Wright M. E., Tappan J. H., and Sister F. E. The size and shape of typical sweet potatoes. Transactions of the ASAE, 1986; 29 (3): 678-68.

[4] Mohsenin N. N. Physical properties of plant animal materialII. Gordon and Breach Sci. Pub, New York, U.S, 1970.

[5] Asoegwu S. N., Eke C. N. U., and Nwandikom G. I. Some Physical Properties of Jackbean Seed (Canavalia ensiformis. $A$. E. I., 2007; 9. the CIGR Ejournal Manuscript FP 07014.

[6] Asoegwu S. N., Ohanyere S. O., Kanu O. P. and Iwueke C. N. (2006). Physical properties of African oil bean seed (Pentaclethra macrophylla). A. E. I, 8. the CIGR Journal of Scientific Research and Development. Manuscript FP. 05006.

[7] Kaleemullah S. and Kailappan, P. Geometric and morphometric properties of chillies. Internat. J. Food Properties, 2003; 6 (3): 481-498. 
[8] Dalvand M. J. (2011). Physical properties of potato tubers cv. Analy. Cult. in iran, 2011; 74: 117-128. DOI: 10.2478/v10032-011-0010-x.

[9] Razavi S. M. A., Emadzadeh B., Rafe A., and Mohammad A. A. The physical properties of pistachio nut and its kernel as a function of moisture content and variety: Part I. Geometrical properties. J. F. E., 2007; 81: 209-217.

[10] Igathinathane C. and Chattopadhyaya P. K. On the development of ready to reckoner table for evaluation surface area of general ellipsoids based on numerical technique. $J$. F. E., 1998; 36 (2): 233-247.

[11] Keramat Jahromi M., Jafari A., Rafiee S., Keyhani A., Mirasheh R., Moh-tasebi S. S. Some Physical properties of Date Fruit (cv. Lasht). The CIGR Ejournal, 2007; 9.

[12] Sahin S., Gülüm Sumnu S. Physical properties of foods. Springer pub., 2006.

[13] Gorji C. A., Rajabipour A. and Mobli H. Post-Harvest Physical and Nutritional Properties of Two Apple Varieties. $J$. A. S, 2010; 2 (3): 1-8.

[14] Stroshine R., Hamann, D. D. (1994). Physical Properties of Agricultural Materials and Food Products. Course Manual. Purdue Univ., USA.

[15] Marvin J. P., Hyde G. M., Cavalieri R. P. (1987). Modeling potato tuber mass with tuber dimensions. Trans. ASAE., 30: 1154-1159.

[16] Deshpande S. D., Bal S. and Ojha, T. P. Physical properties of soybean. J. A. E. Res., 1993; 56: 89-98.

[17] Joshi D. C., Das S. K., and Mukherji R. K. Physical properties of pumpkin seeds. J. A. E. Res., 1993; 54: 219-229.

[18] Gupta R. K. and Das S. K. Physical properties of sunflower seeds. J. A. E. Res., 1997; 66: 1-8.

[19] Nimkar P. M. and Chattopadhyay P. K. Some physical properties of green gram. J. A. E. Res., 2001; 80 (2): 183189.

[20] Baryeh E. A. and Mangope, B. K. Some physical properties of Q. P. -38 variety pegeonpea. J. F. E., 2002; 56 (1): 59-65.

[21] Unal H., Isik E. and Alpsoy H. C. Some physical and mechanical properties of black eyed pea (Vigna unguiculata, L.) grain. Pakistan J. Bio. Sci., 2006; 9 (9): 1799-1806.

[22] Altuntas E. and Demirtola. Effect of moisture content on physical properties of some grain legume seeds. N. Z. J. Crop Hort. Sci., 2007; 35 (4): 423-433.

[23] Altuntas E. and Yildiz M. Effect of moisture content on some physical and mechanical properties of faba bean (Vicia faba L.). Grains. J. F. E., 2007; 78 (1): 174-183.

[24] Shepherd et al. 1986.

[25] Tabatabaeefar A. Size and shape of potato tubers. Int. Agrophysics, 2002; 16: 301-305.

[26] Tabatabaeefar A. and Rahimi M. Physical properties of Iranian potatoes. Proceedings of Inter. Agricul. Eng. Con., 2000b Bangkok- Thailand; 501-506.

[27] Tabatabaeefar A., Rajabipour A. and Khodabandehloo H. Mass model of Iranian export apples with its dimensions. Phy.
Meths in Agri., Prague CZK, 2000a: 303-321.

[28] Tabatabaeefar A., Vefagh-nematolahee A., and Rajabipour A. Mass model of Iranian orange with its dimensions. J. Agric. Sci. Technol., 1999; 2 (4): 299-305.

[29] Owolarafe O. K. and Shotonde H. O. (2004). Some physical properties of fresh okro fruit. J. Food Eng., 63: 299-302.

[30] Sessiz A., Esgici R., Kizil S. (2007). Mois-ture-dependent physical properties of caper (Capparis ssp.) fruit. J. Food Eng., 79: 1426-1431.

[31] Meisami-asl E., Rafiee S., Keyhani A. and Tabatabaeefar A. (2009). Some phys-ical properties of apple cv. 'Golab'. The CIGR Ejournal. 11.

[32] Topuz A., Topakçı M., Çanakçı M., and I. Akıncı Ö. F. Physical and nutritional properties of four orange varieties. $J$. Food Eng., 2005; 66 (4): 519-523.

[33] Safa M. and Khazaei J. Determining and modeling some physical proper-ties of pomegranate fruits of Saveh area related to peeling and packag-ing. In: Int. Cong. on Info. Tech. in Agri., Food and Env., Izmir Turkey, 2003; 331-337.

[34] Taheri-Garavand A., Rafiee S., Keyhani A. and Mirzaee E. A traveling time model as function of water density and vegetable size, shape and density. Veget. Crops Res. Bull., 2010; 73: 143-149. [DOI: 10.2478/v10032-010-0026-7].

[35] Ece Sevgi, Ernaz Altundag, Omer Kara, Orhan Sevgi, Huseyin Baris Tecimen, Ilyas Bolat. Morphological, anatomical and ecological studies on some Orchis (Orchidaceae) taxa of Mediterranean region, Turkey. J. Environ. Biol., 2012; 33: 343-353. ISSN: 0254-8704 CODEN: JEBIDP.

[36] AOAC Official Methods of Analysis of Association of Analytical Chemistry International. $17^{\text {th }}$ ed. Maryland, 2000; 45: 1220 .

[37] Yossry B. Abd Elhay Determination of some physical and mechanical properties of potato tubers related to design of sorting, cleaning and grading machine. Misr J. Ag. Eng., 2017: 34 (3): 1375-1388.

[38] Mohsenin N. N. Physical Properties of Plant and Animal Material. 2nd edition (revised) Gordon and Breach sci. publishers New York, 1986.

[39] McCabe W. L. and Smith J. C. Unit operations of chemical engineering. 3rd Ed., Mc GrawHill book company, Japan; 1984.

[40] Ismail Z. E. Potato cultivar, cultivation, harvesting, handling and storage. Dar EL mearef publisher - Alexandria, 1991; 2357.

[41] Gamea G. R., Abd El-Maksoud M. A. and Abd El-Gawad A. M. Physical Characteristics and Chemical Properties of Potato Tubers Under Different Storage Systems. Misr J. Ag. Eng., 2009.

[42] Reddy B. S, and Chakraverty A. Physical properties of raw and parboiled paddy. Biosys. Eng., 2004; 88, 461-466. http://dx.doi.org/10.1016/j.biosystemseng.2004.05.002.

[43] Varnamkhasti M. G., Mobli H., Jafari A., Rafiee S., Soltanabadi M. H. and Kheiralipour K. Some engineering properties of paddy (var sazandegi). I. J. A. B., 2007; 9: 763766. 
[44] Lewis M. J. Physical Properties of Foods and Food Processing Systems. Ellis Horwood, England, 1987.

[45] Rahman M. S. Food properties handbook. CRC Press, Boca Raton, FL, 1995.

[46] Ozguven F, and Kubilay V. Some physical, mechanical and aerodynamic properties of pine (Pinus pinea) nuts. J. Food Eng., 2004; 68: 191-196.

[47] Dutta S. K., Nema V. K. and Bhardwaj R. K. Physical properties of gram. J. Agric. Eng. Res., 1988; 39 (4): 259-268.
[48] Razavi S. and Milani E. Some physical properties of the watermelon seeds. A. J. A. Res., 2006; 13: 65-69.

[49] Amin M. N., Hossain M. A., and Roy C. Effects of moisture content on some physical properties of lentil seeds. J. Food Eng., 2004; 65: 83-87.

[50] Buyanov A. I. and Voronyuk B. A. Physical and mechanical properties of plant, Fertilizers and soils. Amerind Pub. Co. PVT., LTD., New Delhi, India, 1985; 753. 